\title{
A review on anticipatory grief and lessons learnt from the history of Abu Bakr r.a.
}

\author{
Najwa Hanim M.R ${ }^{1}$, Jefri Irwan $\mathrm{H}^{2}$, Muhammad Al Siddiq S.M ${ }^{3}$, Nor Jannah $\mathrm{N}^{4}$, Zul Azlin $\mathrm{R}^{5}$, Md Faiz M. $\mathrm{T}^{1}$ \\ ${ }^{1}$ Depatment of Psychiatry, Kulliyyah of Medicine, International Islamic University Malaysia ,Kuantan \\ ${ }^{2}$ Global Life Centre (GLC) \\ ${ }^{3}$ Kulliyyah of Hadith and Islamic Studies, Islamic University of Madinah \\ ${ }^{4}$ Dicipline of Psychological and Behavioral Medicine, Universiti Teknologi Mara (UiTM) \\ ${ }^{5}$ Unit Psikiatri, Fakulti Perubatan Sains Kesihatan, Universiti Sains Islam Malaysia (USIM)
}

\section{ABSTRACT}

Grief is defined as 'the internal experience of a person to the loss of something loved and valued'. It is a normal and expected reaction to loss. While anticipatory grief is defined as 'an emotional response that is experienced before a true loss', a concept focusing on that a person might experience grief when the loss of a close loved one was anticipated, but had not yet occurred. The history of Abu Bakr r.a. was reviewed especially from the period of a few months before and recently after the death of the prophet s.a.w. It was noted that he appeared strong while others were down grieving upon the news of the prophet s.a.w.'s death. It was also noted that Abu Bakr r.a. has been grieving when he anticipated that the prophet was going to die. Literatures on anticipatory grief were reviewed. Evidence are conflicting on the role of anticipatory grief. Factors that lead to these differences will be reviewed. The protective factors in Abu Bakr r.a. that helped maintain his composure after the death of prophet Muhammad s.a.w. and later led him to be pledged as the first caliph of the Muslim nation will be discussed.

KEYWORDS: anticipatory grief, anticipatory mourning, bereavement, spirituality, religiosity

\section{INTRODUCTION}

Grief is defined as "the internal experience of a person to the loss of something loved and valued". ${ }^{1}$ It is a normal and expected response to loss. ${ }^{2}$ Anticipatory grief meanwhile, is defined as an emotional reaction that is experienced before an actual loss. Another definition documented is "any grief occurring prior to a loss, as distinguished from the grief which occurs at or after a loss" ${ }^{3}$

Other terms for this situation include preparatory grief or premature grief ${ }^{2}$, a concept focusing on that a person might experience grief when the loss of a close loved one was anticipated, but had not yet occurred. ${ }^{5}$ It encompasses the mourning, coping, and planning of one's life in response to an impending loss as well as future losses. ${ }^{4}$

The aim of this paper is to look at the role of anticipatory grief and other factors throughout the life of Abu Bakr r.a., particularly during the demise of the prophet that makes him the calmest person around after the prophet s.a.w.'s death.

Corresponding author:

Najwa Hanim Md Rosli

Depatment of Psychiatry,

Kulliyyah of Medicine,

International Islamic University Malaysia,

Jalan Sultan Ahmad Shah,

25200 Kuantan,

Pahang, Malaysia

Email: drhoney_mmm@iium.edu.my

\section{DESCRIPTION FROM HISTORY}

Abu Bakr r.a.'s birth name was Abdullah. He was the first free man to embrace Islam and the first person to pray (other than prophet Muhammad s.a.w.). He was 2-3 years younger than prophet Muhammad s.a.w. and yet was also his father-inlaw when the prophet married his daughter 'Aisyah r.a. ${ }^{7}$ He was the prophet's most beloved Companion and also the most knowledgeable as he had spent more time with the prophet as compared to the others. ${ }^{8}$

He cared a great deal for the prophet's well-being and at all times willing to sacrifice his life for the sake of Allah. He had the honor to be the sole Companion of the prophet during the migration to Madinah. It is mentioned in the Qur'an, in Surah AlTawba, "If you help him (Muhammad s.a.w.) not (it does not matter), for Allah did indeed help him when the disbelievers drove him out, the second of two, when they (Muhammad s.a.w. and Abu Bakr r.a.) were in the cave, and he (SAW) said to his Companion (Abu Bakr r.a.): "Be not sad..." (9:40) (9). The term 'the second of two' was referring to Abu Bakr r.a., pertaining to the incident when he was in the cave with the prophet during the migration, hiding from the disbelievers of Mecca. In this verse too, Allah acknowledges Abu Bakr r.a. to be the prophet s.a.w.'s companion. ${ }^{7}$

Towards the end of Muhammad s.a.w.'s life, there were a few instances that hinted the prophet that his death was approaching. For an example, the 
revelation of An-Nasr (110:1-3). ${ }^{6}$ The prophet also at times insinuated his incoming death and only a few Companions understood when the prophet was alluding to his death implicitly. One of them was Abu Bakr r.a. ${ }^{7}$

For an example, referring to a narration by $A b u$ Sa id Al-Khudri, Allah's Messenger s.a.w. spoke to the people saying, "Allah has given option to a slave to choose this world or what is with Him. The slave has chosen what is with Allah." Nobody in the audience recognized the fact that the prophet was referring it to himself except for Abu Bakr r.a., he wept, and at that point of time people could not understand him. The people were astonished when they later learned the truth that the prophet s.a.w. was mentioning about himself when he was referring to a slave (of Allah) who had been offered a choice. Abu Sa id Al-Khudri later mused "Allah's Messenger s.a.w. himself was the person who was given the choice, and that Abu Bakr r.a. was the most knowledgeable among us. ${ }^{9}$

There were also occasions towards the end of his life where Muhammad s.a.w. favoured Abu Bakr r.a. over other Companions to fill his place. Muhammad b. Jubair b. Mut'im narrated on the authority of his father that a woman asked Muhammad s.a.w. about something but he told her to come to him some other time, so she asked: "What in your opinion (should I do) if I come to you but do not find you, (and it seemed as if she meant that he might die). Thereupon he said: If you do not find me, then come to Abu Bakr.". ${ }^{10}$ When Muhammad s.a.w. was very sick, a few days before his passing, Aishah r.a. said, the prophet s.a.w. asked, "Have the people performed the prayer?" "No. They haven't. They are waiting for you." "Put some water in the washing pot." He said. We did what he ordered. So he washed and wanted to stand up, but he fainted. When he came around he asked again "Have the people prayed?" Then the same sequence of events took place again and again for a few times. Thereupon, he sent to Abu Bakr r.a. to lead the prayer himself. Abu Bakr r.a. then led the prayer during those days, seventeen prayers in the lifetime of Muhammad s.a.w. On an occasion, while Abu Bakr r.a. was away, 'Umar r.a. was appointed by the Companions to lead the prayers. Recognizing the change of voice, Muhammad s.a.w. said, "This is not Abu Bakr r.a.'s voice, no one but he should lead prayers, he is the fittest person for this position." 7

Commenting on the state of the Muslims when the prophet s.a.w. died, Ibn Rajab r.a. said: "When Muhammad s.a.w. died, the Muslims were in a state of shock and confusion; some of them were bewildered, others were shocked and started to get things mixed up, others dropped to their knees and were unable to stand, others could not talk and others still refused completely to believe the news of his death."7

During the prophet s.a.w. passing, Abu Bakr r.a. was not in Madinah. 'Aishah r.a. narrated, "When the prophet s.a.w. died, Abu Bakr r.a. was at a place called As-Sunh. 'Umar r.a., stood up and addressed the people saying, "I swear by Allah that the prophet s.a.w. has not died and that Allah will send him back to cut off the hands and legs of those who claim that he has died."

Abu Bakr r.a. then arrived to where the Prophet s.a.w. was lying, uncovered his face, kissed him and said, "I would sacrifice my father and mother for your sake. You are just as fragrant after your death as you were during your life. I swear by the one in whose hand my soul is, Allah will never let you die twice". Then he went out facing the people and said "O you who is swearing (by Allah) (meaning 'Umar) calm down!" When 'Umar r.a. heard Abu Bakr r.a. talking, he kept silent and sat down, so Abu Bakr r.a. praised and thanked Allah and then said, "Whoever was worshipping Muhammad s.a.w., then Muhammad s.a.w. is dead, but whoever was worshipping Allah, then Allah is alive and will never die." Then he recited (that which translates as), "Indeed, you [i.e, Muhammad s.a.w.] are to die, and indeed, they are to die]." (39: 30). And also "Muhammad is not but a messenger. [Other] messengers have passed on before him. So if he was to die or be killed, would you turn back on your heels [to unbelief]? And he who turns back on his heels will never harm Allah at all; but Allah will reward the grateful." (3: 144). ${ }^{11}$

Ibn 'Abbas r.a. said: "By Allah, it sounded as if people had never heard such a Qur'anic verse till Abu Bakr r.a. recited it as a reminder. So people started reciting it till there was no man who did not recite it." Ibn Al-Musaiyab r.a. said that "Umar r.a. had said: "By Allah, as soon as I heard Abu Bakr r.a. say it, I fell down to the ground. I felt as if my legs had been unable to carry me so I collapsed when I heard him say it. Only then did I realize that s.a.w. had really died." 7

In the moment of greatest calamity, Abu Bakr r.a. came in strong. He was later pledged as the first caliph of the Muslim nation.

\section{DISCUSSION}

The term anticipatory grief was first documented by Lindemann in 1944. ${ }^{12}$ He described two examples of two different women of which their male family member(s) were enlisted to serve the armed forces. The first woman was so concerned with the potential loss of her husband or son to the point that she went to all the stage of grief process "depression, heightened preoccupation with the departed, a review of all the forms of death and anticipation of modes of readjustment which might be necessitated by it." This might have been seen to have a protective factor for her should she receive a sudden news of death of her family member which in normal circumstances leads to shock.

However, anticipatory grief might also cause a drawback during reunion, should the male family 
member survive the war. This was documented in the case of the second woman. Her husband reported that his wife became emotionally cold towards him through mail and that she insisted on a divorce once he came back from the war. These two cases sparked a great deal of argument and discussion in the field of medicine in which later led to numerous studies on anticipatory grief.

Research were looking into coping strategies of patient and family members, the effect of anticipatory grief on post death bereavement to care givers and medical staff, characteristics that determine anticipatory grief as being a good or bad prognostic factor in bereavement especially in situations involving terminally ill and demented patients. ${ }^{13,14}$

However, to date, the role of anticipatory grief on post-death bereavement is still inconclusive. A paper reviewing published research on anticipatory grief on post-death bereavement adjustment concluded a spectrum of outcome gained from these studies which included both positive and negative impact, mixed findings and a few showed no relationship between the two. The paper also analyzed possible reasons leading to the conflicting results found between these researches and they concluded that several contributing factors. Among them are differences in the conceptualization of anticipatory grief, lack of precise operational definition and methodological differences; variable related issues such as age differences, gender, personality, length of illness before death and other factors associated with the thought, feeling, behavior, affiliation and communication of the person. ${ }^{15}$

Another systematic review on caregivers researches $^{16}$ on end-of-life caregiving and bereavement also could not confirm the role of grief work before loss would ease bereavement. It also highlighted the issue Linda \& Derek $^{15}$ raised regarding the definition and conceptualization of anticipatory grief that might contribute to this problem. However, one interesting and important finding gained from this study is that high preparedness was associated with improved caregiver outcome. This demonstrated that anticipatory grief is not equivalent to preparedness, and preparedness does not come hand in hand with anticipatory grief.

Another important factor we are interested in when we are looking in grief is the role of spirituality. Bray $^{17}$ in his paper "bereavement and transformation: A psycho-spiritual and post traumatic growth perspective", outlines 2 theoretical frameworks on this matter exploring human potential growth in the struggle through loss; one using post-traumatic growth model and the other psycho-spiritual transformation model. After reviewing and synthesizing a broader model based on the previous two model, he suggested that spirituality and religion seem to play a central role in grief work.
Another controversial issue is perhaps, whether we should promote anticipatory grief if studies indeed convincingly show the favorable outcome. Should we encourage, or 'induce' grief in family members who are caring for terminal stage cancer patient? Ethical consideration is inevitable. However, more importantly, based on the available research, we, as therapists should not discourage people who is about to embark on the grief process prior to the death of the loved ones.

In conclusion, the role of anticipatory grief in post death bereavement is still debatable. However, looking at the factors that has been demonstrated by the studies mentioned above, we can understand that anticipatory grief is multidimensional. Several aspects in Islamic creed ('aqeedah) such as how we look at death and dying, our belief in hereafter and in the only omnipotent, all-knowing God, Allah, should be taken into consideration when attempting to understand anticipatory grief in a Muslim as opposed to in a person of other religion or without any belief in God. A few factors suggesting a better outcome after death happened were also elicited in these studies.

Correlating to the seerah of Abu Bakr r.a., we know that he was the closest Companion to Muhammad s.a.w., he was almost always with Muhammad s.a.w. leading him to become one of the most knowledgeable person around that time and his faith in Allah was among the strongest. He was one of the earliest Companion that understood when the prophet was hinting that his death was near. When Muhammad s.a.w. asked Abu Bakr r.a. to take over certain tasks from him, we believe that this has prepared him to a certain extent for the coming of a great loss to him personally and the Muslim nation in general.

All these factors are believed to be major contributing factors that made Abu Bakr r.a. from the person who wept when no one else was weeping to the person who was the most composed after the death of Muhammad s.a.w. He continued to calm down the ummah when they were in chaos and later was appointed as the first caliph of the Muslim nation.

\section{REFERENCES}

1. Wolfelt $A D$, Duvall KJ. Healing Your Grief About Aging. Fort Collins, CO: Companion Press; 2012.

2. Julia C.S., Lauren M.K., Marianne W.G., Emily S. 2016" Anticipatory Grief An Evidence-Based Approach". Journal of Hospice \& Palliative Nursing. Vol.18(1):15-19

3. Aldrich C. K. "Some dynamics of anticipatory grief.” In Anticipatory Grief (Edited by Schoenberg B., Carr A. C., Peretz D. and Kutscher A. H.). Columbia University Press, New York, 1974.

4. Ferrel B., Coyle N. "Oxford Textbook of Palliative Nursing." New York: Oxford University Press; 2010. 
5. Charles A.C., Donna M.C. "Death \& Dying, Life \& Living." 6th ed. Belmont, CA: Wadsworth; 2009

6. Al - Quran

7. Sheik Safi -ur-Rahman al Mubarak Puri. 2002. "Ar-Raheeq Al-Makhtum (The Sealed Nectar): Biography of the Prophet". Darussalam Publications.

8. Ali Muhammad As-Sallaabee. 2007. "The Biography of Abu Bakr As Siddeeq." Darussalam Publications.

9. Saheeh al-Bukhari. 3654, Book 62, Hadith 6, Vol. 5, Book 57, Hadith 6

10. Sahih Muslim 2386 a, b Book 44, Hadith 11

11. Saheeh al-Bukhari. 3667, 3668 Book 62, Hadith 19, Vol. 5, Book 57, Hadith 19

12. Lindemann E. Symptomatology and management of acute grief. 1944. Am J Psychiatry. 1994 Jun;151(6 Suppl):155-60.

13. Asa KJ, Valter S, Helle RNW, Agneta G. 2013. "Anticipatory grief among close relatives of persons with dementia in comparison with close relatives of patients with cancer". American Journal of Hospice \& Palliative Medicine. 30(1):29-34

14. Linda G, Jennifer H.L., Kaitlyn E.D, Steven T.D, Richard S., Charles F.R., Mary Amanda D. "Anticipatory Grief in New Family Caregivers of Persons with Mild Cognitive Impairment and Dementia Alzheimer Disease \& Associated Disorders." 2012. Vol.26(2): 159-165

15. Linda R., Derek B. 2006. "Anticipatory grief: Its nature, impact, and reasons for contradictory findings." Counselling, Psychotherapy and Health. July.2(2), 15-26

16. Mette K.N., Mette A.N., Anders B.J., Flemming B., Mai-Britt G. 2016. "Do we need to change our understanding of anticipatory grief in caregivers? A systematic review of caregiver studies during end-of-life caregiving and bereavement." Clinical Psychology Review 44: 75-93

17. Peter Bray. 2013. "Bereavement and Transformation: A Psycho-spiritual and Posttraumatic Growth Perspective". Journal of Religion and Health. Sep.52(3):890-903 